\title{
Advertising Arrangements: An Attempt in Improving the Visual Quality of Urban Areas
}

\author{
http://dx.doi.org/10.3991/ijes.v2i4.4038 \\ Endy Marlina ${ }^{1}$, Punto Wijayanto ${ }^{1}$, Dita Ayu Rani ${ }^{1}$, Desrina Ratriningsih ${ }^{1}$ and Tutut Herawan ${ }^{2}$ \\ ${ }^{1}$ Universitas Teknologi Yogyakarta, Yogyakarta, Indonesia \\ ${ }^{2}$ Universiti Malaya, Kuala Lumpur, Malaysia
}

\begin{abstract}
Advertisement plays a role to create an effective communication among societies and urban environment. Its existence has enabled urban society to access information. In the very dynamic era of Yogyakarta society today, advertisement undeniably has been becoming one of the essential components in modern urban landscape. However, inaccuracy of advertisement design conversely can emerge inconvenience and interruption for society. Again it can also lead to the decline of the urban visual quality. Advertisement regulation in Yogyakarta, therefore, is required. In this paper, a study on advertisement regulation in Yogyakarta is conducted using a descriptive-qualitative approach based on the analysis on the communication aspect and spatial aspect. The results are used in recommending for the advertisement regulation based on three criteria: aesthetics, ethics, and safety. Aesthetics is in consideration of cultural values suitable in Yogyakarta (Local Regulation of Special District of Yogyakarta (DIY) No.4/2011) and visual consideration (American Society of Landscape Architects, 1979). Meanwhile, ethics is in accordance with Government Regulation 109/2012 and Law No. 11 Year 2010 and safety, in turn, is in accordance with Government Regulations No. 34 year 2006 and Regulations on Building No. 28 Year 2002.
\end{abstract}

Index Terms-Arrangement of advertisement; Aesthetics; Ethics; Safety; Urban area.

\section{INTRODUCTION}

Dynamism in life development has led to the increase of society needs for any commercial products. This then contributes to the emergence of mushrooming advertisement as one of commercial communication devices. In Special District of Yogyakarta (locally abbreviated as DIY), this phenomenon is remarked by how complex the issue is in installing an advertising device or sign in certain area for involving certain interests: the interest of the advertisement installers, the interest of the authority of the area where the advertising sign is placed, and the interest of society seeing the advertisement. On the other side, the existence of the advertising signs in an urban space frequently blocks the sight to the urban elements that, in fact, are interesting such as the building architecture and the urban landscape elements. Hence, an advertisement regulation is deemed essential. This is in line with the opinion of Sunarimahingsih (2013) stating that inaccuracy in advertisement designs, in turn, can emerge the inconvenience and interruption for society. Even, it can lead to the decline of the urban visual quality.

Based on the dynamics of development of installing the advertising signage in Yogyakarta, a number of issues can be identified as follows: a. Discrepancy between the existing master plan for the advertisement regulation and the development of the recent condition of the advertising signage layout

b. Unavailability of evaluation data for the existing condition of advertisement regulation

c. Unidentified issues and potentials for the development of advertisement regulation

d. Unavailability of a comprehensive plan for advertisement regulation complete with a draft appropriate with urban development and environment condition and

e. Unavailability of recommendation for the policy of advertisement regulation

The presence of the very significantly increasing advertisement in Yogyakarta nowadays more strengthens the reason about the needs for a guideline on regulation appropriate with the development of Yogyakarta at recent and a prediction for future development.

\section{RELATED WORKS}

Defined in the Great Dictionary of Indonesian Language (KBBI) (1991), advertisement refers to an announcement to public about a commercial product complete with interesting words and pictures purposely to make the product sold. Quoted from what is defined by Ewald and Mandelker (1971), advertisement is known as Street Graphics. In the Regulation of the Major of Yogyakarta Number 26 Year 2010 about the Master plan of Advertisement and Visual Aids in Yogyakarta City, advertisement is defined as a thing, tool, action or media in which the form and motif of them are designed for a commercial purpose, introducing, suggesting, promoting or for attract the public attention to the product, service, people or body that can be seen, listened, felt, or enjoyed by public. An advertisement is functioned to create an effective communication between society and environment in urban area. Its presence has provided an information access for urban society. It cannot be denied that the advertisement, also called as outdoor publicity, is an important component in a landscape of modern city. It is suggested that an advertisement is harmoniously integrated with the built environment design (Gordon Cullen in Townscape, 1962). According to Shirvani (1985), an ideal principle of advertisement should be:

1. Capable of reflecting the visual characteristics of a region

2. Capable of guaranteeing a viewpoint that can be clearly seen 
3. Having a form that is appropriate with the architecture of the building where the signage is posted

4. As the elements harmoniously integrated with the building - not as an additional element that can distract the visual

5. Capable of uniting the communication directly or indirectly

In the Regulation of Indonesia Republic Number 28 Year 2002 about Building Construction, it is found that an advertisement is categorized as building that can be considered as a physical form of a construction work integrated with the space of its position either partly or entirely on/under land underground and/or water. Based on this perception, the advertisement is included into building. The requirements of the building architecture account for appearance, balance, compatibility, and harmony with its environment and the consideration towards the existing balance between the local social-cultural values and the implementation of any development of architectures and engineering.

In the Government Regulation of Indonesia Republic Number 36 Year 2005 about the Implementation of Law and Regulation Number 28 Year 2002 about the Building Construction, it is found that the appearance of the building located in a cultural site must be designed by considering the conservational principles. The appearance of the building built bordering on the conserved buildings must be designed by considering the principles of building aesthetics. Based on the Local Regulation of Yogyakarta city Number 2 year 2012 about Building Construction it is stated that infrastructure and facilities of a building refer to the interior and exterior facilities of a building that can support the fulfilment of building function integrally or independently. The infrastructure and facilities of the building also function as advertisement/signage including billboards, or advertising boards separately or in the form of wall.

Based on the Government Regulation Number 109/2012 about the Controlling Additives Substances in the form of Tobacco Products, the government does a control to the advertisement of tobacco products. This control is conducted through printed media, broadcasting media, media of Information Technology and/or outdoor media by doing the following actions:

1. Attaching the health warning in the pictorial and written form sized at least $10 \%$ of total duration of the advertisement and/or $15 \%$ of total width of advertising signage

2. Attaching the code of " $18+$ " in the advertisement of tobacco products.

3. Not demonstrating, using and/or displaying the form of cigarette or other equal forms that can be associated with the trademark of tobacco products.

4. Not mentioning the product name as cigarette

5. Not describing or suggesting that smoking provides benefit for health

6. Not using the misled words or sentences

7. Not stimulating or suggesting other to smoke

8. Not presenting child, teenager and/or pregnant women in the pictorial or written forms

9. Not being addressed to child, teenager and/or pregnant women
10. Not using animation figures as the model of the advertisement

11. Not being on the contrary with norms acceptable in society.

In addition to the control of tobacco product advertisement, the outdoor media must fulfil some conditions as follows:

1. Not being placed at non-smoking area

2. Not being placed at the main or protocol streets

3. Must be placed parallel with the roadside and cannot cross the road or be transverse and

4. Not allowed to be more than $72 \mathrm{~m}^{2}$ in size

Based on the Regulation of Ministry of Public Works Number 20/PRT/M/2010 about Guidelines in Utilization and Usage of Road Parts, it is found that Road Usage Space (Ruang Manfaat Jalan) and Right On Way (Ruang Milik Jalan) can be used for the advertising construction and information media. This utilization, however, must fulfil the following requirements:

1. Not distracting security and safety of the road users

2. Not distracting the sight and the concentration of the motorists

3. Not distracting the function and the construction of the roads and its complementary buildings

4. Not distracting and reducing the function of the signs and other traffic control facilities

5. In accordance with the local regulation and/or the regulation of relevant authorities

6. Form of the advertisement and information media cannot be equal or resemble to the traffic signs

For the security and safety for the road users, the building of advertisement and information media must fulfil the following requirements:

1. It must be made of durable and stainless materials fulfilling the general requirements of building materials in Indonesia and

2. The main frame must be in the form of steel or concrete construction fulfilling the standard of construction regulations in Indonesia

Advertisement and information media can use the lamp in accordance with the following requirements:

1. The intensity of lamp light does not dazzle the road users and

2. The reflection of the lamp light does not dazzle the road users

Furthermore, both letters and colour of the advertisement and information media must fulfil the following requirements:

1. The form of the letter or symbol used in advertisement and information media cannot be equal or resemble to the form of the letters and the symbols as in the traffic signs and

2. The combination of the colour used in the advertisement and information media cannot be equal or resemble to the colour used for the traffic signs

The building construction of the advertisement and information media must be designed safer so that when the buildings are damaged or collapsed, it will not endanger 
the road users, road construction and road building complementary. To ensure security and safety of the road users, the construction of the advertisement and information media and electrical installation in the advertisement and information media must comply with the following technical requirements:

1. Regulation on building load

2. Regulation on steel building plan

3. Regulation on building materials

4. Regulation on concrete building plan and

5. Regulation on electrical installation

The building construction of advertisement and information media should not be in the form of portal and/or any constructions crossing the street, specifically intended to advertisement and information media. In this case, advertisement and information media on the road network in urban areas can be placed on the road usage space, of course, with the following requirements:

1. Placed on the outside roadside or pavement at least 1 (one) meter from the outer edge of the shoulder of the road or pavement

2. In the case of unavailability of outside roadside, pavement, or traffic, the advertisement and information media can be placed on the outer Right On Way.

3. Advertisement and information media on the road network outside urban areas can be placed on the outer Right On Way.

4. Advertisement and information media can be installed on the bridge structure without endangering the bridge construction and the safety of the road users.

5. Advertisement and information media on the Right Usage Space must be placed at a height of at least 5 (five) meters of the highest road surface.

Related to the spatial plan, advertisement should have been a regulatory element at the level of RDTR (Detail Spatial Plan). Meanwhile its designated area (zoning) is at the level of RTRK (Spatial Land Settlement Plan). In more detail, advertisement comes to be a part considered in Urban Design Pattern and Urban Structure which commonly are issued in Plan for Building and Environment (RTBL). Based on those regulations, the advertisement regulation should concern with the following points:

1. Environment Aesthetics Standard in order to support the aesthetic of environment.

2. Advertisement Saturation related to the number of the advertising signage installed in a particular area, thus needed to be limited.

3. The significance of the decision regarding the ban on the advertising signage installation in free zone and restricted zone for any advertisements.

4. The significance of control system from authority in monitoring the illegal advertisements and

5. The significance of precision in design and size of installed advertising signage based on the proposed design and size.

\section{Methodology}

This study was conducted using a qualitativedescriptive approach based on the analysis on the aspects of communication and space. Communication aspect here is used as the base for the advertisement regulation by considering that advertisement is one of social or commercial communication media. Meanwhile, spatial aspect is used as the base of the advertisement regulation by considering that advertisement is one of the urban design components. Overall, this study comprises the following stages:

\section{A. Survey on data collection}

It is a stage of identifying the existing condition of advertisement order that includes the order of the advertising signs, buildings, and space nearby. Data collection was conducted either directly to obtain primary data or indirectly to obtain secondary one. In collecting the primary data, two methods were used:

\section{1) Observation and Field Survey}

This was done by directly observing the existing advertisements. The result of this observation was then mapped in the form of database. The observed primary data in this case included the spots of existing advertisements, type and size of the existing advertisements, method of installing advertising signage, number of each advertisement type, and classifying the advertisement materials (cigarette and non-cigarette).

\section{2) Interview}

Interviews with several government agencies were to obtain information about the current condition regarding the implementation of advertisement. On the other hand, literature study was used in collecting secondary data both from a number of government agencies, here related to regulation and implementation of advertisement such as the materials relevant with the policy of advertisement implementation, previous policy on advertisement regulation and policies related to the advertisement regulation.

\section{B. Analysis}

It is a phase of analyzing the existing condition about the advertisement structure by referring to the existing policies, literatures and direction for the spatial development and trend of society dynamics in future. The results of this analysis were then used as the bases in formulating recommendations for advertisement order.

The data and information obtained were systematically organized to obtain any matters that must be analyzed such as:

a. Policy Review - It includes studies related to policies and directions for spatial planning in Yogyakarta, study on Regulations of Mayor related to the master plan of previous advertisements and study on Local Regulation, in particular regarding arrangement and tax of advertisement.

b. Literature Review - It includes a study on the definition of advertisement and the one on advertisement design.

Furthermore, the obtained data was analyzed for the evaluation of the existing advertisement regulation in Yogyakarta and for the formulation of any potential to development and issues related to the advertisement regulation in Yogyakarta. 
PAPER

ADVERTISING ARRANGEMENTS: AN ATTEMPT IN IMPROVING THE VisuAl QUALITY of URBAN AREAS

\section{Formulating The Concept Of Recommendations For Advertisement Regulation}

It is done using a participatory planning strategy in a limited scope through representatives based on their expertise. Some competent parties in this case were involved such as government, private sector, and stakeholders in advertising world. Meanwhile, participation of community was accommodated through a number of interviews. In a rural area, the increase of advertisements (social and commercial ones) seems to be obvious. At the moment, advertisement has been becoming a crucial rural element that needs to be appreciated in the design of urban environment. The rapid growth and the increasing number of advertising signage, in turn, will bring a positive impact for the local taxes, especially for Yogyakarta. Hence, an anticipatory action from government is needed in this case related to its regulation.

A limited amount of land in a rural area should become a concern for advertisers, both as business people and as advertising agencies. The procurement of advertisement in future, therefore, needs a better consideration both in concept and in communication method. Such review in this case is particularly related to the quality issue. By so doing, it will be more effectively useful in shaping the opinions of the candidates of consumer. Advertisement regulation is deemed necessary to create harmony in an environmental visual in order to maintain the city image. For this reason, a comprehensive guidance for the advertisement regulation is required to maintain beauty, comfort, and safety of the city using the following considerations:

1. Space (spot) for installation that needs to be adjusted in accordance with the function of space utilization.

2. Given the saturation at one spot due to the stacks of advertisement exceeding capacity.

3. Scale and proportion of open space coming to be a consideration in accommodating advertisement based on the size, number and type.

4. The stack and the line of advertising signage resulting in a low visual effect making it hard for the observers to absorb the information on the advertising signage.

5. Media of advertisement and visual forms that has an influence on community activities that in turn affect the safety and comfort of regularity and face the city environment

\section{RESULTS AND DISCUSSION}

\section{A. Definition of Advertisement}

By considering its definition as stated in Regulation of Yogyakarta Mayor No. 26 in 2010 on the Master plan of Advertisement and Aids in Yogyakarta City and based on the scientific review of Ewald and Mandelker (1971), advertisement can be defined as objects, tools, action or media based on its form and pattern modes that is designed to introduce, encourage, promote, or attract public attention to goods, services, person or institution that can be seen, read, heard, felt, and / or enjoyed by public. Based on the results of observations and analysis on 66 road cut-offs in Yogyakarta, a change on the advertisement type, as listed in the policy of advertisement implementation year 2007, was found. To accommodate the growth and dynamics of public life today and in future, advertisement can be classified into the following types:

1. Advertising boards/billboards - It is was a flat or curved shaped billboard containing static images and/or text made of wood, metal, fibre glass/glass, plastic and other similar materials depending on the times. It can be completed with or without light and its installation can be separately or stuck on the building with a fixed and permanent construction including the dynamic wall, trivision and running text.

2. Videotron / Megatron - It also is a flat or curved shaped advertisement containing movable/live/visual images and/or text with or without audio in the screen construction in a form of LCD, LED or other equivalent things installed separately or stuck on the building with fixed and permanent construction.

3. Cloth Billboard - It is an advertisement in the form of banners and flags made of fabric material

4. Vinyl/Plastic billboard - It is an advertisement in the form of banners, rontek and made of vinyl/plastic materials. The installation of this might be separately or stuck on the building in the temporary or semipermanent construction.

5. Attached Advertisement/stickers - It is flat or curved-shaped advertisement made of paper, plastic/vinyl, or metal. The installation of it is by attaching to the building using glue in the semi-permanent form.

6. Leaflet advertisement - it is an advertisement in the form of sheet paper, plastic or vinyl commonly directly distributed to people in a semi-permanent form.

7. Walking advertisement (including in vehicle) - it is a plane or curved shaped advertisement made of wood, metal, fibre glass/glass, plastic or any equivalent materials based on the times. Its installation is on mobile vehicles or pedestrians and it is mobile.

8. Aerial advertisement - it is such advertisement made of plastic, rubber, cloth, paper or other equivalent material based on the times hovering in the air. It is semi-permanent and installed separately or attributed to buildings or aircraft.

9. Floating advertisement - It is an advertisement made of wood, metal, fibre glass/glass, plastic or other equivalent material based on the times and floating on the water.

10. Voice advertisement - It is a semi-permanent advertisement in the form of broadcasting or utterance by means of electronic audio equipments.

11. Show Advertisement - It is a semi-permanent advertisement using certain materials given in the form of performance by carrying, exhibiting and wearing.

12. Light/Movie/Slide Advertisement - It is a semipermanent or permanent advertisement presented in a flat or curved media containing static or dynamic pictures or texts with or without audio and emitted by the projector such as rear screen, beamvertising, or virtual.

\section{B. Form of Advertisement}

The increasing dynamics of people life has brought an impact on the increase of the needs for information. This 
is then responded through the increasing number of advertising signs as the communication media to offer products, services, or any activities. Based on these studies, the form of advertisement can be categorized as follows:

1. Based on its position on the road, the advertisement is divided into the longitudinal one or unidirectional to the road and the transverse one or crossing the road.

2. Based on its length and width, the advertisement is categorized into vertical one and horizontal one.

3. Based on angle of view, advertisement is categorized into one-sided advertisement, two-sided advertisement and multi-sided one.

4. Based on the size, the advertisement is divided into big-sized one if it is $25 \mathrm{~m} 2-32 \mathrm{~m} 2$ in size, mediumsized one if in the range of $12 \mathrm{~m} 2-<24 \mathrm{~m} 2$ in size, and small-sized one if sized $<12 \mathrm{~m} 2$.

Of the existing types of advertisement, particularly for the size of light advertisement, the form will be adapted based on the width of media used. Table 1 presents the recommendation of the form of advertisements in detail.

As mandated in District Spatial Plan (locally abbreviated as RTRW) of Yogyakarta in 2010, the image of Yogyakarta city is addressed to reflect the aspects of education, struggle, tourism, and cultural-based service. This is in line with the vision of Yogyakarta: "Yogyakarta as Qualified Education City, Cultural-Based Tourism and Centre for Environmentally Sound Service". To support this vision, the aesthetics aspect must be well-considered in the implementation of advertisement. The increasing number of the installed advertising signage must be in control to keep the zonal or rural identities, some of which have been existed from the existing buildings on it. This consideration then is becoming the base of the following recommendations for the advertisement implementation related to the facade of building and historical building.

1) The installation of the advertising signage attached on building must be maximum $40 \%$ (forty per cent) of the facade width.

Such installation commonly is used to the billboard of the shop name and recommended to be the one that must be attached on the facade without any additional constructions.

The installation of the advertising signs attached on the facade can be done by using the space on the facade (with the number at $40 \%$ of the facade width) or by vertically attaching the advertisement on the facade as shown in Figure 1. The types of the advertisements placed on the facade can include Billboard, Videotron or threedimensional one.

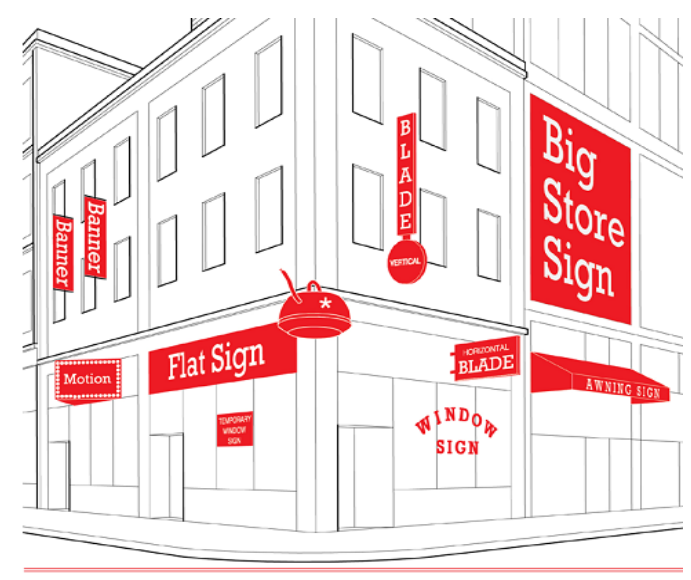

Figure 1. Recommendation for the types of Advertisement Installation on Façade (Source: Construction of Researcher, 2013)

TABLE I.

RECOMMENDATION OF ADVERTISEMENT FORM

\begin{tabular}{|c|c|c|c|c|c|c|c|c|c|c|c|}
\hline \multirow[b]{2}{*}{ No } & \multirow[b]{2}{*}{$\begin{array}{l}\text { Types of Ad- } \\
\text { vertisement }\end{array}$} & \multicolumn{2}{|c|}{$\begin{array}{l}\text { Based on the posi- } \\
\text { tion to the road }\end{array}$} & \multicolumn{2}{|c|}{$\begin{array}{l}\text { Based on the position } \\
\text { of length and width }\end{array}$} & \multicolumn{3}{|c|}{$\begin{array}{c}\text { Based on the Angle of } \\
\text { View }\end{array}$} & \multicolumn{3}{|c|}{ Based on size } \\
\hline & & $\begin{array}{c}\text { Longitu- } \\
\text { dinal } \\
\text { unidirec- } \\
\text { tional }\end{array}$ & Transverse & Vertical & Horizontal & $\begin{array}{l}\text { One- } \\
\text { sided }\end{array}$ & $\begin{array}{l}\text { Two- } \\
\text { sided }\end{array}$ & $\begin{array}{l}>\text { two- } \\
\text { sided }\end{array}$ & $\begin{array}{c}\operatorname{Max}(25 m 2-32 \\
m 2)\end{array}$ & $\begin{array}{c}\operatorname{Med}(12 m 2-<24 \\
m 2)\end{array}$ & $\begin{array}{r}\text { Mini }(< \\
12 \mathrm{~m} 2)\end{array}$ \\
\hline 1 & $\begin{array}{l}\text { Advertisement } \\
\text { Board / } \\
\text { Billboard }\end{array}$ & $\mathrm{v}$ & $\mathrm{v}$ & $\mathrm{v}$ & $\mathrm{v}$ & $\mathrm{v}$ & $\mathrm{v}$ & $\mathrm{v}$ & $\begin{array}{l}\text { For the spot of } \\
\text { advertisement } \\
\text { installed on the } \\
\text { artery roadside }\end{array}$ & $\begin{array}{l}\text { For the spot of } \\
\text { advertisement } \\
\text { installed on the } \\
\text { collector roadside }\end{array}$ & $\mathrm{v}$ \\
\hline 2 & $\begin{array}{l}\text { Videotron/ } \\
\text { Megatron }\end{array}$ & $\mathrm{v}$ & $\mathrm{v}$ & $\mathrm{v}$ & $\mathrm{v}$ & $\mathrm{v}$ & $\mathrm{v}$ & & $\begin{array}{l}\text { For the spot of } \\
\text { advertisement } \\
\text { installed on the } \\
\text { artery roadside }\end{array}$ & $\begin{array}{l}\text { For the spot of } \\
\text { advertisement } \\
\text { installed on the } \\
\text { collector roadside }\end{array}$ & $\mathrm{v}$ \\
\hline 3 & Fabric & \multicolumn{10}{|c|}{ Incidental, maximal 1 month for installation on the determined road } \\
\hline 4 & vinyl/plastic & \multicolumn{10}{|c|}{ As a form of compensation of contribution to public facilities with the knowledge and approval of authorized government } \\
\hline 5 & $\begin{array}{l}\text { Attached/ } \\
\text { Sticker }\end{array}$ & \multicolumn{10}{|c|}{ As a form of compensation of contribution to public facilities with the knowledge and approval of authorized government } \\
\hline 6 & Leaflets & \multicolumn{10}{|c|}{ Incidental, not emerging any disturbance to environment, fulfilling the consideration in aesthetics, ethics, and safety } \\
\hline 7 & Walking & \multicolumn{10}{|c|}{ Incidental, not emerging any disturbance to environment, fulfilling the consideration in aesthetics, ethics, and safety } \\
\hline 8 & Aerial & \multicolumn{10}{|c|}{ Adjusted with the width of media used } \\
\hline 9 & Floating & \multicolumn{10}{|c|}{ Adjusted with the width of media used } \\
\hline 10 & Voice & \multicolumn{10}{|c|}{ Adjusted with the width of media used } \\
\hline 11 & Show & \multicolumn{10}{|c|}{ Incidental, not emerging any disturbance to environment, fulfilling the consideration in aesthetics, ethics, and safety } \\
\hline 12 & Light/film/slide & \multicolumn{10}{|c|}{ Adjusted with the width of media used } \\
\hline
\end{tabular}

Source: Construction of the researcher, 2013 
Other installations for the Advertisement of Company Name or Profession Identification are as follows:

a. The advertising signs are installed horizontally or unidirectional and vertically or crossing the road. The advertising signs should not block the building ornaments including windows and detail of architecture. In addition, the design of the advertisement must be integrated to the building. For the installation of advertising signs in the vertical position to the road, it is recommended as follows:

1) The maximum distance for the installation is 1 meter or half of pavement (depending on which one firstly taken) with the height distance of minimal 3 meter from pavement.

2) The design of advertisement form can be onesided and two-sided with $15 \mathrm{~cm}$ in maximum for the thickness of the advertising board.

3) The position of the length and width of advertisement form might be vertical or horizontal.

b. The advertisement in horizontal position (unidirectional to the road) must be really visible at distance to make the information delivered much easier to be transferred to the users. The dimension of the advertisement, in addition, must be $40 \%$ (forty per cent) at maximum from the width of facade as described in Figure 2.

2) A cultural-site building is not allowed to be used as an advertising media with the exceptions:

a. Business/Profession Advertisement with the provision of $10 \%$ at maximum form the facade width and $1.5 \mathrm{~m}$ at maximum height and/or

b. Light advertisement

The detailed recommendations for the installation of advertising construction on the building facade are presented in Table II.

\section{Advertising Placement}

The Decree of Ministry for Internal Affair No 15 year 1999 states that the strategic value of the advertisement spots is highly determined by a number of factors such as Spatial Usage or the potential of the region in achieving the target of installing the advertising sign, size of the advertisement, angle of view of advertisement, road class, and the price of spot of the advertising sign installation. Those strategic values then lead to the needs for the control from the local government towards the advertising placement. The effectiveness of outdoor advertisement to deliver information is reflected through the target achievement that is the number of societies accepting the information. This is influenced by the consideration of the advertisers in selecting the location of the advertising sign installation determined by (Kasali, 1993): Spatial Usage, road class, and road cut-offs.

The considerations above are based on the function of the advertisement as the information media. In this way, the advertisement settling can be managed as follows:

1. The advertising placement on the bulge land of personal individual or institution can be done in hall (see Table 1), by attaching it on the frontage and on the side of building or inside the building (see Table 2 ). The advertising placement on the bulge land of personal individual or institution must still refer to the regulated government policy.

2. The advertising placement on the bulge land of personal individual follows certain rules regarding form, placement, and size of the advertising signage adjusted to the road class in front. At the primary road class, the advertisement settling on the bulge land of individual is allowed until a maximal size with the distance among the $\geq 9-\mathrm{m} 2$ advertisements at least at 200 meters and its maximum number for 7 advertisements in each road space. The number of beamed advertisement in one space of bulge land is for 1 advertising construction at maximum.

3. The advertising placement on the bulge land of government and/or public facilities can be done on the pavement, bus halt, market/terminal/Smart Park /parking Park, schools or government institution.

4. The advertising placement on the bulge land of government and/or public facilities is NOT RECOMMENDED to be done on the lamp posts, traffic lamp post, pergola, overpass, portal, clock pillar, police station and signpost except as a compensation for the contribution to a public facility given with the knowledge and approval of authorized government with provision that the compensational advertisement sized at $5400 \mathrm{~cm} 2$ or $30 \%$ of facade width (depending on which one firstly taken).

The advertising placement in an environmental park area or in Green Space Area is NOT RECOMMENDED except as a compensation for the contribution to public facilities consigned with the knowledge and approval of authorized government provided that the maximum size of the compensation advertisement is at $2400 \mathrm{~cm} 2$ or $20 \%$ of facade width, depending on which is firstly achieved. This is referred to the Laws No 26 Year 2007 about Spatial Plan stating that this area is intended for green zone purposely to sustain the environment balance.

A variety of bulge lands of government and their characteristics as public facilities has opened a great opportunity for the installation of advertisement. However, there is a need to regulate this free access make the implementation of advertisement in that area or facilities still consider the aspect of aesthetics, ethics, and safety and in line with the existing policy on spatial plan to maintain the appearance of city as mandated.

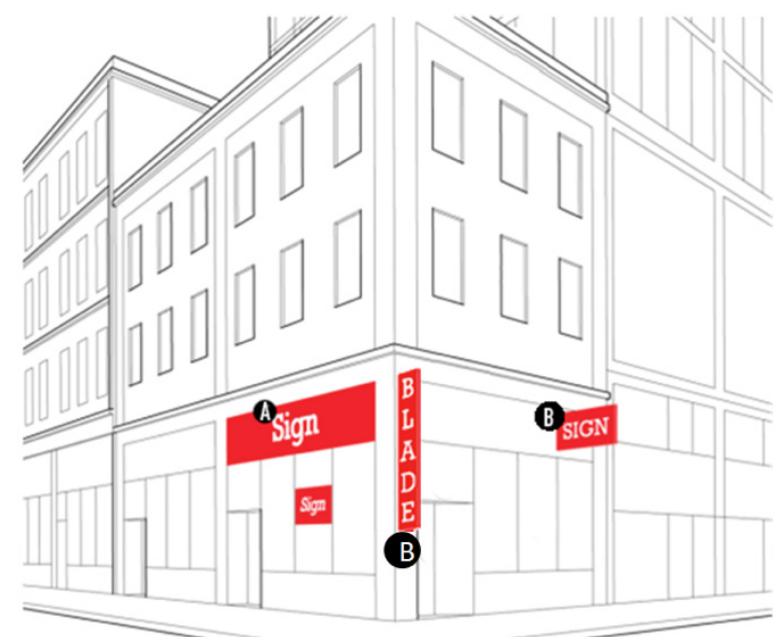

Figure 2. Recommendation of Advertising Signage Installation on Facade (Sources: Construction of Researcher, 2013) 
TABLE II.

RECOMMENDATION FOR ADVERTISING CONSTRUCTION INSTALLATION ON THE BUILDING FACADE

\begin{tabular}{|c|c|c|c|}
\hline \multirow{2}{*}{ No } & \multirow{2}{*}{$\begin{array}{l}\text { Types of Adver- } \\
\text { tisement }\end{array}$} & \multicolumn{2}{|c|}{ Installation by Attaching on Facade } \\
\hline & & Horizontally/unidirectional to the road & Vertically/Crossing the road \\
\hline \multirow{5}{*}{1} & \multirow{5}{*}{$\begin{array}{l}\text { Advertising Board } \\
\text { /billboard }\end{array}$} & $\begin{array}{l}\text { 1. Not allowed to block the building ornaments including } \\
\text { windows and architectural detail }\end{array}$ & $\begin{array}{l}\text { 1. Not allowed to block the building ornaments including } \\
\text { windows and architectural detail }\end{array}$ \\
\hline & & $\begin{array}{l}\text { 2. Advertisement design must also be integrated to the build- } \\
\text { ing }\end{array}$ & $\begin{array}{l}\text { 2. Advertisement design must also be integrated to the } \\
\text { building }\end{array}$ \\
\hline & & $\begin{array}{l}\text { 3. The dimension of the advertisement is maximally } 40 \% \\
\text { (forty per cent) of the facade width }\end{array}$ & $\begin{array}{l}\text { 3. The maximum distance to build is } 1 \text { meter or half of the } \\
\text { pavement width (depending on which one firstly taken) with } \\
\text { the height distance of minimal } 3 \text { meters from pavement }\end{array}$ \\
\hline & & \multirow{2}{*}{$\begin{array}{l}\text { 4. For the advertisement to } 2 \text { ) the cultural site building, it is } \\
\text { only allowed for the business/professional advertisement } \\
\text { with the provisions at maximal } 10 \% \text { (ten per cent) of the } \\
\text { width of facade and the highest level of height at } 1.5 \mathrm{~m} \text { (one } \\
\text { point five meter) }\end{array}$} & $\begin{array}{l}\text { 4. The design of the advertisement can be in a one-sided or } \\
\text { two-sided form with maximal } 15 \mathrm{~cm} \text { in thickness of adver- } \\
\text { tising board. }\end{array}$ \\
\hline & & & $\begin{array}{l}\text { 1. The length and width position of the advertisement form } \\
\text { might be vertical and horizontal. }\end{array}$ \\
\hline \multirow{5}{*}{2} & \multirow{5}{*}{$\begin{array}{l}\text { video- } \\
\text { tron/megatron }\end{array}$} & $\begin{array}{l}\text { 1.Not allowed to block the building ornaments including } \\
\text { windows and architectural detail }\end{array}$ & $\begin{array}{l}\text { 1. Not allowed to block the building ornaments including } \\
\text { windows and architectural detail }\end{array}$ \\
\hline & & $\begin{array}{l}\text { 2. Advertisement design must also be integrated to the build- } \\
\text { ing }\end{array}$ & $\begin{array}{l}\text { 2. Advertisement design must also be integrated to the } \\
\text { building }\end{array}$ \\
\hline & & $\begin{array}{l}\text { 3. The dimension of the advertisement is maximally } 40 \% \\
\text { (forty per cent) of the facade width }\end{array}$ & $\begin{array}{l}\text { 3. The maximum distance to build is } 1 \text { meter or half of the } \\
\text { pavement width (depending on which one firstly taken) with } \\
\text { the height distance of minimal } 3 \text { meters from pavement }\end{array}$ \\
\hline & & \multirow{2}{*}{$\begin{array}{l}\text { 4. For the advertisement to } 2 \text { ) the cultural site building, it is } \\
\text { only allowed for the business/professional advertisement } \\
\text { with the provisions at maximal } 10 \% \text { (ten per cent) of the } \\
\text { width of facade and the highest level of height at } 1.5 \mathrm{~m} \text { (one } \\
\text { point five meter) }\end{array}$} & $\begin{array}{l}\text { 4. The design of the advertisement can be in a one-sided or } \\
\text { two-sided form with maximal } 15 \mathrm{~cm} \text { in thickness of adver- } \\
\text { tising board. }\end{array}$ \\
\hline & & & $\begin{array}{l}\text { 4. The length and width position of the advertisement form } \\
\text { might be vertical and horizontal. }\end{array}$ \\
\hline 3 & Fabric & Not recommended & Not recommended \\
\hline \multirow{5}{*}{4} & \multirow{5}{*}{ vinyl/plastic } & $\begin{array}{l}\text { 1. Not allowed to block the building ornaments including } \\
\text { windows and architectural detail }\end{array}$ & $\begin{array}{l}\text { 1. Not allowed to block the building ornaments including } \\
\text { windows and architectural detail }\end{array}$ \\
\hline & & $\begin{array}{l}\text { 2. Advertisement design must also be integrated to the build- } \\
\text { ing }\end{array}$ & $\begin{array}{l}\text { 2. Advertisement design must also be integrated to the } \\
\text { building }\end{array}$ \\
\hline & & $\begin{array}{l}\text { 3. The dimension of the advertisement is maximally } 40 \% \\
\text { (forty per cent) of the facade width }\end{array}$ & $\begin{array}{l}\text { 3. The maximum distance to build is } 1 \text { meter or half of the } \\
\text { pavement width (depending on which one firstly taken) with } \\
\text { the height distance of minimal } 3 \text { meters from pavement }\end{array}$ \\
\hline & & \multirow{2}{*}{$\begin{array}{l}\text { 4. For the advertisement to } 2 \text { ) the cultural site building, it is } \\
\text { only allowed for the business/professional advertisement } \\
\text { with the provisions at maximal } 10 \% \text { (ten per cent) of the } \\
\text { width of facade and the highest level of height at } 1.5 \mathrm{~m} \text { (one } \\
\text { point five meter) }\end{array}$} & $\begin{array}{l}\text { 4. The design of the advertisement can be in a one-sided or } \\
\text { two-sided form with maximal } 15 \mathrm{~cm} \text { in thickness of adver- } \\
\text { tising board. }\end{array}$ \\
\hline & & & $\begin{array}{l}\text { 5. The length and width position of the advertisement form } \\
\text { might be vertical and horizontal. }\end{array}$ \\
\hline \multirow{5}{*}{5} & \multirow{5}{*}{ attached/sticker } & $\begin{array}{l}\text { 1. Not allowed to block the building ornaments including } \\
\text { windows and architectural detail }\end{array}$ & $\begin{array}{l}\text { 1. Not allowed to block the building ornaments including } \\
\text { windows and architectural detail }\end{array}$ \\
\hline & & $\begin{array}{l}\text { 2. Advertisement design must also be integrated to the build- } \\
\text { ing }\end{array}$ & $\begin{array}{l}\text { 2. Advertisement design must also be integrated to the } \\
\text { building }\end{array}$ \\
\hline & & $\begin{array}{l}\text { 3. The dimension of the advertisement is maximally } 40 \% \\
\text { (forty per cent) of the facade width }\end{array}$ & $\begin{array}{l}\text { 3. The maximum distance to build is } 1 \text { meter or half of the } \\
\text { pavement width (depending on which one firstly taken) with } \\
\text { the height distance of minimal } 3 \text { meters from pavement }\end{array}$ \\
\hline & & \multirow{2}{*}{$\begin{array}{l}\text { 4. For the advertisement to } 2 \text { ) the cultural site building, it is } \\
\text { only allowed for the business/professional advertisement } \\
\text { with the provisions at maximal } 10 \% \text { (ten per cent) of the } \\
\text { width of facade and the highest level of height at } 1.5 \mathrm{~m} \text { (one } \\
\text { point five meter) }\end{array}$} & $\begin{array}{l}\text { 4. The design of the advertisement can be in a one-sided or } \\
\text { two-sided form with maximal } 15 \mathrm{~cm} \text { in thickness of adver- } \\
\text { tising board. }\end{array}$ \\
\hline & & & $\begin{array}{l}\text { 5. The length and width position of the advertisement form } \\
\text { might be vertical and horizontal. }\end{array}$ \\
\hline 6 & Leaflet & - & - \\
\hline 7 & Walking & - & - \\
\hline 8 & Aerial & - & - \\
\hline 9 & Floating & - & - \\
\hline 10 & Voice & - & - \\
\hline 11 & Show & - & - \\
\hline 12 & Light/film/slide & - & - \\
\hline
\end{tabular}

Source: Construction of Researcher, 2013 
One of essential aspects needed to be well considered in the practice of advertisement implementation is the aspect of safety. The Regulation of Minister of Public Works Number 20/PRT/M/2010 about The Guideline of the Utilization and Usage of Road Parts has regulated the relationship between the advertisement implementation and safety as described in Figure 3.

The above policy has been a base of the following recommendations in the advertising placement in Yogyakarta:

1. Advertisement is not allowed to be conducted on divider roads and Green Space Area

2. Advertisement is not allowed to be conducted in the form of wall painting in considering that it can distract the concentration of the road users - particularly for motorists.

3. Advertisement is not allowed to be conducted in the form of portal or in any other constructing types that cross the road - particularly the one intended to an advertisement implementation.

4. Advertisement is not allowed to be conducted in the form of fabric except for banners and flags. One of the methods of installing an advertising sign mostly found is by crossing on the roads. This absolutely is not recommended as such advertisement is easy to be worn and will distract the sight of the road users.

5. Advertisement is not allowed to be conducted in the form of large front light billboard. In this case, the front light can cause a light reflection that can distract the visual comfort of the road users.

In addition to safety, aesthetics also becomes a base for the recommendation for not implementing the advertisement using a media of fabric/vinyl/plastics in a space of main roads in Yogyakarta including at the streets of Laksda. Adi Sucipto, Urip Sumoharjo, Jend. Sudirman, P. Mangkubumi, Malioboro and Ahmad Yani.

Similarly, the aspects of ethics and aesthetics are also highly needed to be considered in making the implementation of advertisement can support the policy on spatial planning in order to make Yogyakarta beautiful and harmonious. To prevent the stacks of advertising boards on the cross road, a free-advertisement area on the cut-off road in the radius of 25 meters from the cross road is highly recommended then as described in Figure 4.

To keep maintaining the urban appearance, it is recommended that the installation of advertising signage on a road cut-off is placed by 200 meters inter-spots of advertisement as described in Figure 5.

Other recommendation to minimize the number of advertising media is by giving priority towards the use of Videotron. 2 spots of videotron are placed at the corner of the road cut-off. If the road is one-way direction, the videotron will only be placed in one of the corners. Meanwhile, in two-way direction, the videotron will be placed in each corner of the roads cut-off in accordance with the direction of the vehicles as described in Figure 6.

\section{Advertisement Content}

In general, based on its content, an advertisement can be categorized into commercial and Visual Aids advertisement. Commercial advertisement includes the ones for professional business, products, and business and products. Meanwhile, what is meant by visual aid advertise-

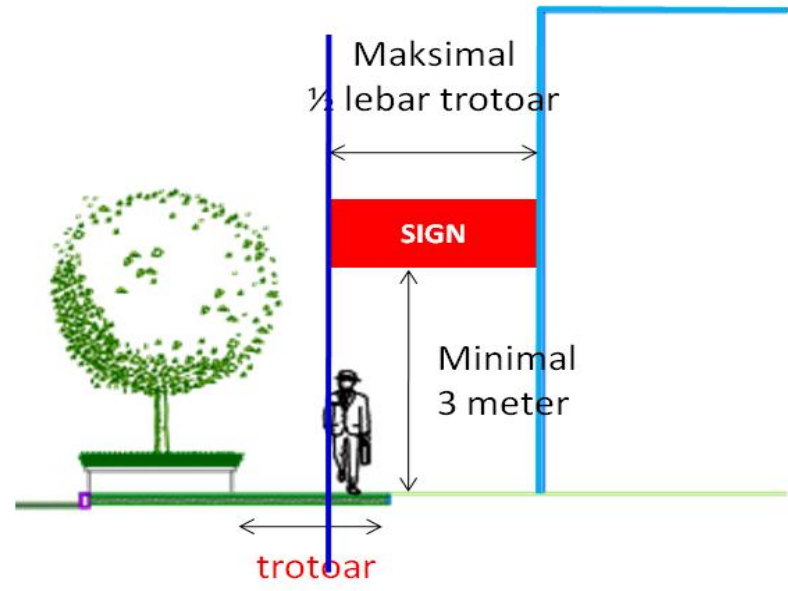

Figure 3. Recommendation to Advertisement Installation (Source: Construction of Researcher, 2013)

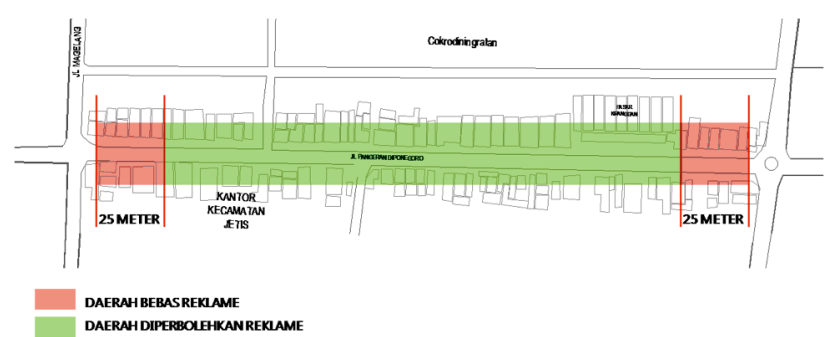

Figure 4. Free-Advertisement Area on the Cut-Off Roads (E.g. on the cut-off road at Diponegoro Street), Source: Construction of researcher, 2013)

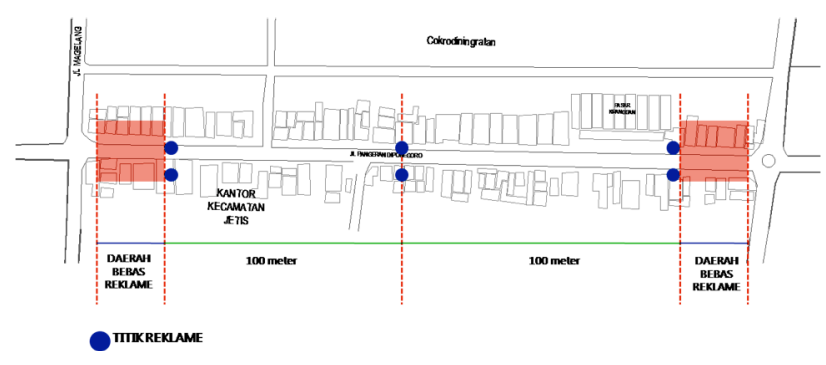

Figure 5. Recommendation of Advertisement Spots (e.g. on the cut-off road at Diponegoro Street con), Source: Construction of Researcher, 2013

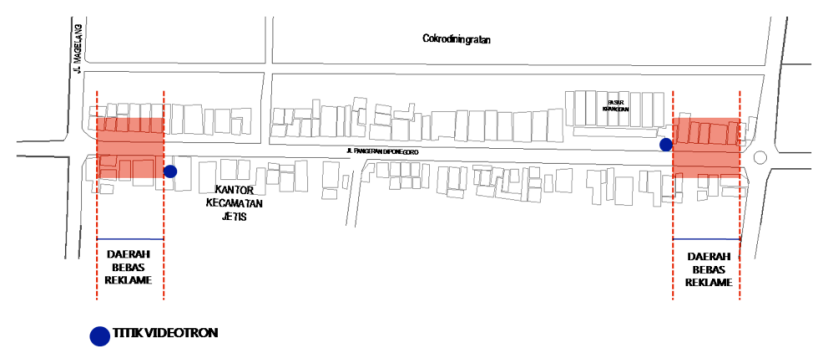

Figure 6. The recommendation of the Spots for the Videotron Advertisement (E.g. on the cut-off road at Diponegoro Street), (Source: Construction of Researcher, 2013)

ment is the type of advertisement regarding noncommercial advertisement that might contain social and political information. Visual aid can be categorized into visual aids and visual aids and advertisement. The later is due to the existence of advertisements found to contain both commercial and non-commercial information at all once. 
The essential point needed to be concerned here is to make the content of advertisement in line with the local cultural values. It is then highly recommended if the content of an advertisement can emphasize on the main local cultures. This is to support the vision of Yogyakarta as a qualified education city, cultural-based tourism and centre for environmental service as mandated in the policy of spatial city plan of Yogyakarta in 2010. The more detail regulation about the content of cultural values needs to be further explained to avoid the emergence of ambiguity among society.

In this study, any advertisements containing tobacco product are found. The recommendation about such advertisement is based on the Government Regulation Number $109 / 2012$ about the security on the additive substances in the form of Tobacco Products. In this policy, the government conducts a control on the tobacco product advertisement. This policy is becoming a base for the following recommendations on the settling of an advertisement containing information regarding the tobacco products or any alcoholic liquor.

1. Not to place any advertisements containing cigarette and/or alcoholic liquor products in or outside school areas in the radius of 50 meters (fifty meters). However, the existence of public facilities in Yogyakarta, some of which are near schools makes it possible to be an exception for the regulation that is for an incidental advertisement containing cigarette products at the area of Mandala Krida Stadium and Kridosono Stadium in relation to the events in that areas.

2. Not to place any cigarette product advertisement in any non-smoking area at the main or protocol streets, either in the crosswise or in the crossing position on the road and the size not exceeding $72 \mathrm{~m}^{2}$ in size (seventy-two square meters)

\section{E. Advertising Zone}

Referring to the Regulation of Yogyakarta Mayor Number 25 Year 2013 about the Elaboration of Spatial Planning and Condition of Land Use Intensity, the advertisement implementation in Yogyakarta region can be classified into three zones:

1. Special Zone - It is a zone free from any advertising administration -except for the types of advertisement with the following provisions:

a. Advertisement for business/professional signage attached on the building. Such advertisement is regulated as follows:

i. The facade of building attached by advertising board/ billboard sized at 1.5 meter in height and the length of advertisement field adjusted to each floor of the building.

ii. The right and/or the left side of the building facade attached with an advertising board or billboard sized 2.5 meter in height and the length of the advertising field adjusted to the building for each floor.

iii. The installation of the light advertisement in building in which the size and the form of the advertisement are adjusted to the building facade.

iv. The installation of videotron/megatron attached on the building facade - except the cultural site building. This type of advertisement should be $40 \%$ at maximum of the width of the building facade.

b. For the service on public information and product advertisement, government or in cooperation with other parties determines and provides the spots of the advertisement.

c. The incidental advertisement for any event calendar is allowed only in the area of Alun-Alun Utara, Alun - Alun Selatan and Alun - Alun Sewandanan Pakualaman.

2. Tight Control Zone Zone refers to a zone where the advertisement administration is allowed by considering the cultural site zone

3. Medium Control Zone refers to a zone besides special zone and tight control zone

Referring to the Regulation of Yogyakarta Mayor Number 25 Year 2013, a number of special zones that are recommended are including:

1. Area of Tugu (pillar) with the radius of $50 \mathrm{~m}$ (fifty meters) from Tugu Pal Putih;

2. Pangeran Mangkubumi Street

3. Malioboro Street

4. Ahmad Yani Street

5. Area of 0 (zero) $\mathrm{km}$ with the radius of $50 \mathrm{~m}$ (fifty meters) from the middle of intersection

6. Trikora Street

7. Alun -alun utara

8. Alun-alun selatan

9. Alun-alun Sewandanan Pakualaman

10. Buildings of Plengkung Gading and Plengkung Wijilan

11. Pojok Beteng Area

\section{F. Structure of Advertisement}

An advertising sign requires a strong construction in order to support the load occurred both from the load itself and from external factor (wind and earthquake). The construction of an advertisement can be divided into two:

1. Lower-Part Construction (See Figure 7) This construction is in the lower part of advertisement located above or parallel with the ground. In general, the foundation functions both as the lowest component of support structure and as the last element transferring the load down to the ground.

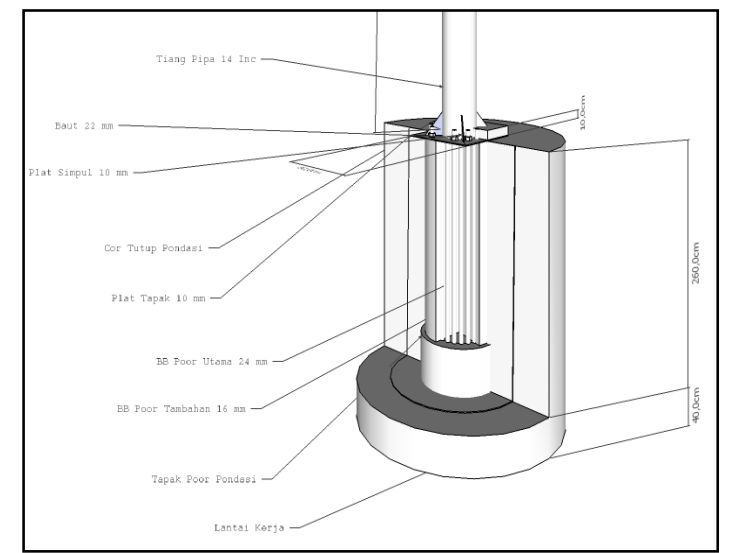

Figure 7. Recommendation of Advertisement Foundation Structure (Source: Construction of researcher, 2013) 


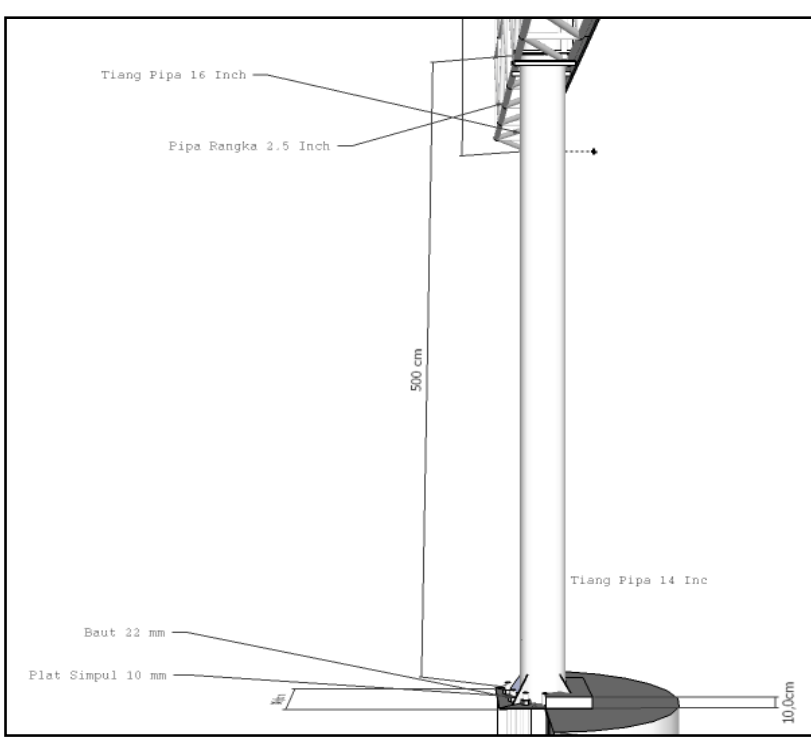

Figure 8. Recommendation of Advertisement Pole Structure (Source: Construction of Researcher, 2013)

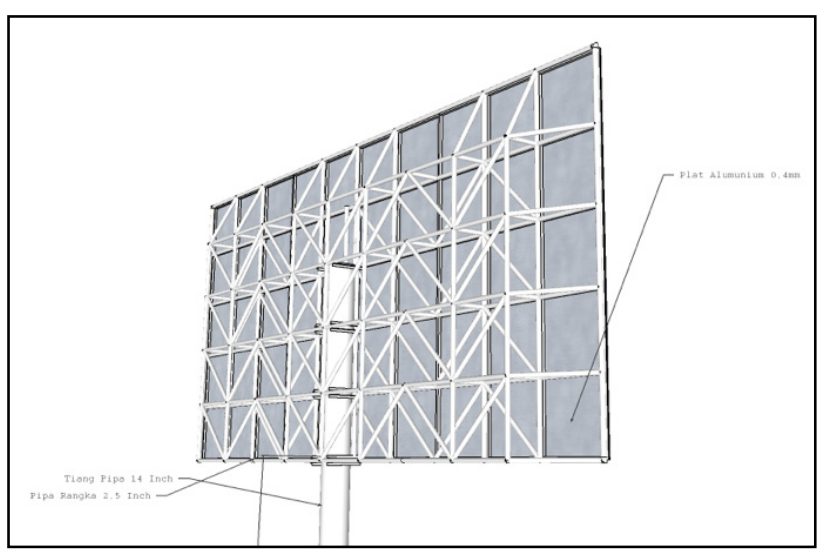

Figure 9. Recommendation of Advertisement Stanchion Structure (Source: Construction of Researcher, 2013)

2.Upper-Part Construction : this construction is the main construction in an advertising sign consisting of:

a. Stanchion (column) (See Figure 8): It is a component of advertisement construction functioned to support the load above and distributing it to the foundation. In general, this component is made of steel pipe or steel frame.

b. Main Frame (See Figure 9): It is a component of advertisement construction functioned to locate the field of advertisement. In common, it is made of steel frame.

3. Advertisement Construction Plan: In planning a construction, essential data is importantly needed to prevent the error in calculating that can lead to the failure of construction.

In planning a foundation, it requires:

1. Data on soil mechanics in which from this data, support capacity of soil can be identified in a determined depth; thus it makes possible to plan the foundation correctly without exceeding the support capacity of soil.

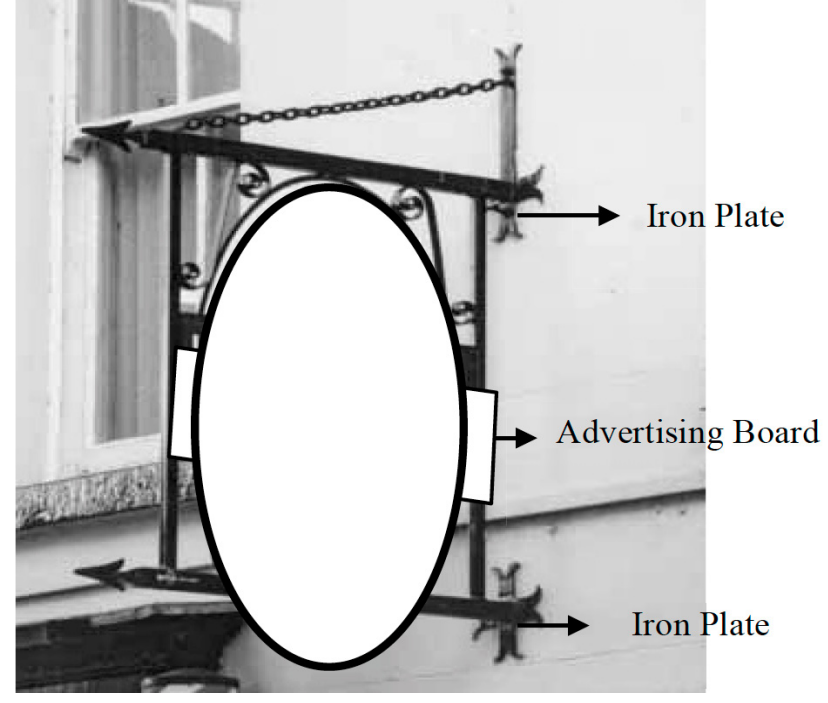

Figure 10. recommendation of Attached Advertisement Construction (Source: Construction of Researcher, 2013)

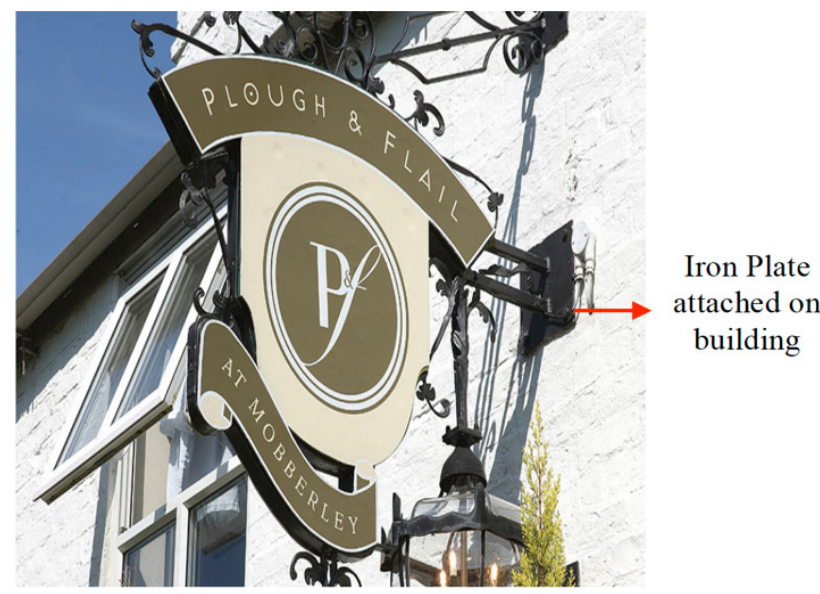

Figure 11. Sample of Construction Recommendation (Source: Construction of Researcher, 2013)

2. Load supported by foundation obtained from the result of structure calculation.

In planning this construction, the following loads are used:

1. The load of the construction itself. It is a load of all construction components including frame, advertising board, and lamp along with its accessories. For the load of frame, it can be identified from the material specification obtained from the steel producer.

2. Load from people when working on it or when maintaining - with an assumption that the weight of one person is $100 \mathrm{~kg}$.

3 . The wind load highly dominant with the rate assumption at $50 \mathrm{~km} /$ hour or less than $156.25 \mathrm{~kg} / \mathrm{m} 2$.

The construction of advertisement attached on a building must concern with a building structure. In this case, the construction of building structure must be able to support the load of the advertisement both from frame and from its media. In supporting the load, the construction must be placed on the building block for giving safety and strength compared to be attached on the wall. The installation of the attached advertising board must use an iron plate functioned to strengthen the advertisement construction as described in Figures 10 and 11. 


\section{CONCLUSION}

The increasing number of advertisements in a rural area frequently causes the decline in quality of urban visual for example by blocking the sight to the rural elements actually interesting to see such as building architectures, and the elements of rural landscape. By referring to the Law of Indonesia Republic Number 28 Year 2002 about Building Structure, an advertisement refers to one of building structures. In other word, it is a physical form of a construction work integrated with its position place and has a particular function. Hence, like a building structure, advertisement is also given certain requirements of building structure including:

1. Architectural requirements comprising appearance, balance, compatibility and harmony of advertisement to environment.

2. Appearance Requirement - an advertisement must concern with the form and characteristic of the architecture and environment nearby

The design of advertising board must possess the uniqueness of certain ornaments derived from the society culture. To support the achievement of vision of Yogyakarta, design is recommended to be developed using the various ornaments of Yogyakarta. Ornament refers to a decorative item applied to decorate something to be beautiful. In a building, ornament can be attached on the building both on structural or non-structural part in the form of the object itself or only on the surface. The characteristics of the various ornaments can be seen from the motive or form, pattern, colour and materials used to beautify a building. In its nature, ornaments can only be functioned as a complement for both exterior and interior of building. A form can be related to the exterior appearance that can be identified. A form in addition has a number of visual characteristics such as shape, dimension, colour and textures.

Yogyakarta is a city that is rich of cultures, one of which is its architectural ornaments that range from simple to complex one - for example floral (plant) and faunal (animal) ornaments, nature and religion (belief). The floral ornaments for example include "lung-lungan", "saton" and "tlacapan". Meanwhile, the faunal ornaments for example are "kemamang", "peksi garuda" and "mirong". Furthermore, the natural ornaments might include "gunungan", makutha" and "mega mendhung" and the religious ornaments might include "mustaka", and "calligraphy". For the bamboo ornaments, it can be in the form of cane work as described in Figures 12 and 13.

In addition to the type of advertisement for signage, the advertising type mostly common to find is the advertisement of directional signs to certain location. These boards are standing on each of pole thus possible to corrupt the city face. As the solution for the issue, it is recommended to unite it into 1 . Besides being separately placed on one pole, advertisement actually can use the street furniture installed along the road (in the form of Bus Halte of Trans Jogja), on the map of Yogyakarta and other strategic places.

To guarantee the law and order and compatibility of advertisement implementation practice to the policies that have been set out, the advertisement implementation can be managed through the following provisions.

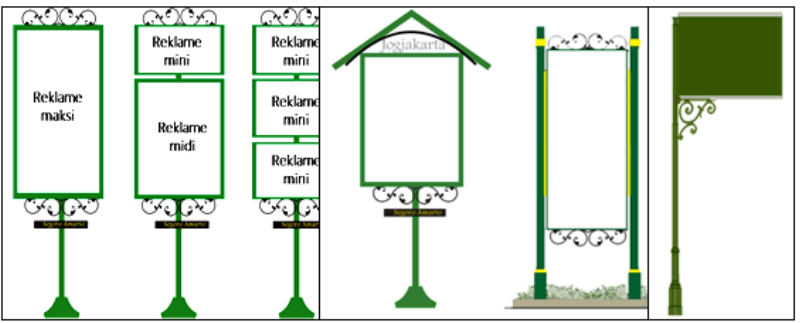

Figure 12. Recommendation of Advertisement Design (Source: Construction of Researcher, 2013)

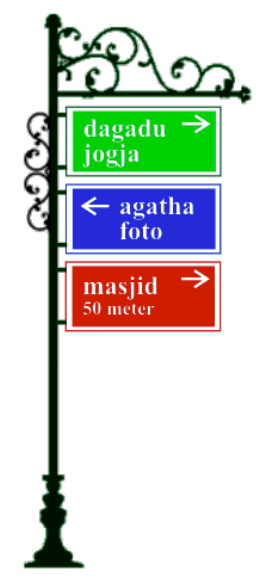

Figure 13. Recommendation of Advertising Signage Design (Sources: Construction of Researcher, 2013)

1. The advertisement implementation must be initiated through the licence process. Each of advertisement implementation in a local is obliged to have licence from Major or the assignee.

2. To obtain the licence, the advertiser must fulfil a number of administrative and technical requirements set out by the local government.

3. Requirements, procedure, and validity period of licence of advertisement implementation are regulated by the competent government.

4. To guarantee the law and order of advertisement implementation, control from assigned authority is needed based on a clear guideline of control

5. Any violation to the regulation regarding the advertising implementation can be imposed an administrative sanction and/or criminal prosecution in accordance with the regulation issued.

\section{REFERENCES}

[1] Carr, Stephen, M. Francis, L.G. Rivlin, A.M. Stone, 1992, Public Space, Cambridge University Press, New York

[2] Djojodipuro, Marsudi, 1992, Teori Lokasi, Lembaga Penerbit Fakultas Ekonomi Universitas Indonesia, Jakarta

[3] Gibbons, Johanna and Oberholzer Bernard, 1992, Urban Streetscapes: A Work Book for Designers, Van Nostrand Renhold

[4] Juniarko, Oky, 2010, Penataan Reklame Pada Koridor Jalan Utama Kota Maratam, Journal of Urban and Local Spatial Plan, Volume 1, Number 2, July 2010

[5] Kelly, Eric Damian and J. Raso Gary, 1993 Sign Regulation for Small and Midsize Communities: A Planners Guide and A model Ordinance, MAI

[6] Lynch, Kevin, 1960, the Image City, MIT Press, Cambridge, Massachusetts

[7] Mawardi, Moh.,1998, Studi Alternatif Bentuk Lembaga Pemerintahan Kota untuk Pembinaan dan Pengelolaan kota Ra- 
PAPER

AdVERTISING ARRANGEMENTS: AN ATtEMPt IN IMPROVING THE ViSUAL QUALITY OF URBAN AREAS

ba-Bima, Thesis, Master Program of City and Region Plan, Postgraduate Program of Institut Teknologi Bandung, Bandung

[8] Natalivan, Petrus, 1996, Pedoman Teknis Penataan Media Reklame Luar Bangunan (Contoh Kasus Kotamadya Daerah Tingkat II Bandung), Final Assignment, Department of Planology, ITB, Bandung

[9] Local Regulation of Palu Region, Number 10, 2005, Restribusi Izin Pemasangan Sarana Publikasi

[10] Russel, Thomas and Verril, Glenn, 1986, Otto Klepper's Advertising Procedure,

[11] Saaty, Thomas L. and Vargas, Lis G., 1994, Decision Making in Economic, Political, Social and Technological Environments: The Analytic Hierarchy Process, RWS Publications, Pittsburgh

[12] Setiawan, Altim, 2005, Pengaruh Permasalahan Transportasi Terhadap Ruang Publik, Mektek Journal, Vol VII No. 1 January 2005

[13] Setiawan, Altim, 2009, Kajian Faktor Nilai Strategis Lokasi Dalam Penempatan Reklame Di Kota Palu, "ruang "Journal, Volume 1 Number 1, September 2009

[14] Shirvani, Hamid, 1985, the Urban Design Process, New York, Van Nostrand Reinhold, Co.Bnbn

[15] Siagiaan, SP., 1982, Sistem Informasi untuk Pengambilan Keputusan, PT. Gunung Agung, Jakarta.
[16] Major Decree, No. 15/WK/2002 about Determination of advertisement Values in Palu City

[17] Sunarimahingsih, 2013, Signifikansi Papan Reklame Di Pusat Kota Semarang, Journal of Scientific Study Volume 15, Number 1.

[18] Sutte, Donald T, 1993, the Appraisal of Out Advertising Signs, Appraisal Institute, US

[19] Watson, Donald; Plattus, Alan; Shibley, Robert, 2001, Time-Saver Standards for Urban Design, McGraw-Hill

\section{AUTHORS}

Endy Marlina, Punto Wijayanto, Dita Ayu Rani, and Desrina Ratriningsih are with the Department of Architecture, Faculty of Science and Technology, Universitas Teknologi Yogyakarta, Jl. Ring Road Utara, Jombor, Sleman, Yogyakarta, Indonesia.

Tutut Herawan is with the Department of Information System, Universiti Malaya, Pantai Valley, Kuala Lumpur, Malaysia.

This work is supported by Universitas Teknologi Yogyakarta Research Grant. Submitted 13 July 2014. Published as resubmitted by the authors 25 October 2014. 